\title{
Entrepreneurship as Elixir and Mutagen
}

Erik Lundmark and Alf Westelius

\section{Linköping University Post Print}

\section{Tweet}

N.B.: When citing this work, cite the original article.

Original Publication:

Erik Lundmark and Alf Westelius, Entrepreneurship as Elixir and Mutagen, 2014, Entrepreneurship: Theory \& Practice, (38), 3, 575-600.

http://dx.doi.org/10.1111/etap.12004

Copyright: Wiley: 24 months

http://eu.wiley.com/WileyCDA/

Postprint available at: Linköping University Electronic Press

http://urn.kb.se/resolve?urn=urn:nbn:se:liu:diva-82103 
ENTREPRENEURSHIP AS ELIXIR AND MUTAGEN

\author{
MANUSCRIPT ACCEPTED SEPT 2012 FOR PUBLICATION IN \\ ENTREPRENEURSHIP THEORY \& PRACTICE \\ ERIK LUNDMARK, MACQUARIE UNIVERSITY \\ ALF WESTELIUS, LINKÖPING UNIVERSITY
}

The authors wish to thank the editor, Benson Honig, and three anonymous reviewers for guidance and insightful comments. The paper has also benefited from comments by Peter Bryant and Mattias Nordqvist. 
ENTREPRENEURSHIP AS ELIXIR AND MUTAGEN, Erik Lundmark \& Alf Westelius

Manuscript accepted for publication in Entrepreneurship Theory Practice

\title{
ENTREPRENEURSHIP AS ELIXIR AND MUTAGEN
}

\begin{abstract}
Metaphors are powerful tools for sensemaking, sensegiving and theory development, but they are often concealed in academic writing. This paper uncovers two metaphors underlying entrepreneurship discourse and research - elixir and mutagen. The elixir metaphor is uncovered by examining critiques of entrepreneurship research and serves as a compact description of problematic aspects entrepreneurship scholars should be mindful of. The mutagen metaphor is uncovered by examining evolutionary frameworks, focusing on the role entrepreneurship plays in them. The paper illustrates how the mutagen metaphor can be used to reframe entrepreneurship and uses the metaphors to interest, inform and provoke.
\end{abstract}

\section{INTRODUCTION}

Metaphors are powerful tools for sensemaking, sensegiving and theory development (Cornelissen, 2006; Hill \& Levenhagen, 1995; Weick, 1989). This paper focuses on the metaphors underlying entrepreneurship research, so-called root metaphors (Pepper, 1982). Such metaphors are integrated in theoretical models and basic assumptions (Boxenbaum \& Rouleau, 2011). Root metaphors are important because they profoundly influence both people's perceptions and the way people make sense of those perceptions (Lakoff \& Johnson, 1980). Consequently, root metaphors influence not only theoretical models and the empirical focus of scholars, but also the interpretations of empirical material. Making these metaphors explicit, therefore, helps scholars scrutinize assumptions and biases in past, present and future research. In addition, making underlying metaphors explicit facilitates dialogue and theory development, through enabling creative combinations of multiple perspectives (Boxenbaum \& Rouleau, 2011).

Research focusing on and using metaphors is established within the entrepreneurship field, but has to date primarily focused on the use of metaphors outside of the academic community. For example, some scholars have studied the metaphors for entrepreneurship used by entrepreneurs (Koiranen, 1995; Hyrsky, 1999; Dodd, 2002) and non-entrepreneurs (Koiranen, 1995; Hyrsky, 1999). Others have studied the metaphors media use to portray entrepreneurs (Nicholson \& Anderson, 2005). Yet others have studied how entrepreneurs use metaphors for sensemaking and sensegiving (Hill \& Levenhagen, 1995). However, the use of metaphors for entrepreneurship within the academic community is under-researched. While, for example, the organizational studies field has made its metaphorical building blocks explicit (Morgan, 1986), there is a gap between the implicit and explicit use of metaphor that remains to be filled in the entrepreneurship literature. Although there is some use of explicit metaphors for entrepreneurship among scholars, such as engine of growth (Audretsch, 2009), method (Sarasvathy \& Venkataraman, 2011) and parenthood (Cardon, Zietsma, Saparito, Matherne, \& Davis, 2005), uncovering root metaphors within academic research is 
difficult because metaphors are sometimes employed subconsciously and they are often made invisible in academic writing (Boxenbaum \& Rouleau, 2011).

Through assessing the underlying implicit use of metaphors in entrepreneurship discourse and research, this paper uncovers two root metaphors for entrepreneurship elixir and mutagen. The paper illustrates how the uncovered root metaphors frame entrepreneurship and it uses these frames in order to "interest, inform and provoke", objectives Aldrich (1992, p. 38) suggested research should strive for.

The elixir metaphor is uncovered by joining three strands of critique of entrepreneurship research. This metaphor, once uncovered, reveals that entrepreneurship can sometimes be construed as a cure-all, as a medium concealing the taste of a bitter medicine, as the key to economic success and as a revitalizer. The elixir view is associated with several complications. For example, it can nudge researchers towards positive interpretations of research findings relating to entrepreneurship, it confuses the discourse and it screens out destructive aspects logically included in the core definition emergence of new economic activity, which is the definition suggested by Davidsson and Wiklund (2001) and Wiklund, Davidsson, Audretsch and Karlsson (2011).

The second root metaphor, mutagen, is uncovered by examining evolutionary frameworks and the role entrepreneurship plays in them. This paper finds that entrepreneurship is portrayed as a source of variation and as an inducer of mutations, which corresponds well with the function of a mutagen in biological evolution. Further examined, the mutagen metaphor exhibits a remarkable fit with entrepreneurship. This paper therefore moves on to using the mutagen metaphor as a means to reframe entrepreneurship through disciplined imagination (Weick, 1989).

The next section of this paper explains our use of metaphors. The subsequent section uncovers the elixir metaphor. The complications highlighted by the elixir metaphor are also presented. Thereafter, the paper uncovers the mutagen metaphor and assesses the fit between entrepreneurship and mutagen. It then gives examples of how the mutagen metaphor can be used to reframe entrepreneurship. The paper concludes by discussing the findings and by noting the extent to which the mutagen metaphor moderates the complications associated with the elixir one.

\section{METAPHORS AS RESEARCH TOOLS}

A metaphor is a comparison between two knowledge areas or conceptual domains. Those using metaphors borrow an expression - the metaphor - from a source domain and apply it to a target domain. As soon as someone labels a category or an instance of a phenomenon, the label becomes a metaphor that emphasizes some aspect or aspects of the phenomenon it categorizes and downplays others. However, because the target and the source domain are not equivalent, some aspects are bound to exhibit poor correspondence. For example, while the well-established metaphor of entrepreneurship as parenthood (Cardon et al., 2005) highlights important aspects of entrepreneurship, such as that entrepreneurs often have strong emotional ties to their firms and that the firm is vulnerable in the early stages, trying to draw far-reaching analogies between child upbringing and the relationship between entrepreneurs and firms would probably not be fruitful beyond some point. Furthermore, the parenthood metaphor could give rise to nonsensical transfer of meaning, for example, that it takes a man and a woman to start a 
firm. The possibility of such nonsensical transfer of meaning does not, however, mean that the analogies regarding emotional ties or vulnerability would become less valid.

Language is full of metaphors, explicitly or implicitly affecting how people understand the world they live in (Lakoff \& Johnson, 1980). Metaphors can also be used to convey research results forcefully or as a pedagogical tool (Weick, 1989; Czarniawska \& Sköldberg, 1998; Cornelissen, 2006). This tool is used also by entrepreneurship scholars. For example, Bygrave and Zacharakis (2011) start their successful textbook, which depicts a plant in the palms of two hands on its cover, as follows:

The green shoots of entrepreneurship give an economy its vitality. They give rise to new products and services, fresh applications for existing products and services, and new ways of doing business. Entrepreneurship stirs up the existing economic order and prunes out the dead wood. Established companies that fail to adapt to the changes cease to be competitive in the marketplace and go out of business. (p. vii)

This text is full of metaphorical language; it alludes to gardening, plants, creative destruction and to evolution or survival of the fittest.

Increasingly, metaphors are viewed as useful research tools, which can be used systematically to conduct thought experiments and to discipline imagination (Morgan, 1986; Weick, 1989; Palmer \& Dunford, 1996; Czarniawska \& Sköldberg, 1998; Cornelissen, 2006). However, such use is not necessarily described or even acknowledged in academic journal articles (Boxenbaum \& Rouleau, 2011).

There are entrepreneurship scholars who engage in metaphor research. Attempting to capture what it feels like to be an entrepreneur, Dodd (2002) collected metaphors used by North American entrepreneurs to describe entrepreneurship. Typically, these metaphors centered on discontinuity and the joys and tribulations of the process of creation. In a similar study, Hyrsky (1999) explored metaphors employed by North Europeans to capture the essence of entrepreneurial activity. These metaphors tended either to present glorifying images or to convey negative, cynical and downgrading undertones. As Dodd (2002) noted, these empirically grounded metaphors capture more emotional aspects than the models employed by researchers.

This paper follows up on the detached researcher perspective and concentrates on academic discourse on entrepreneurship. It also illustrates how the academic discourse is intertwined with that of policy makers. The paper strives to uncover root metaphors that can help us better understand and explore entrepreneurship. A root metaphor is a metaphor that captures a central idea around which a complex problem can be organized (Pepper, 1982). A root metaphor is applicable to a strain of research or subfield, not just to the work of a single researcher. However, no single metaphor captures everything, and root metaphors need not be mutually exclusive. In fact, previous research shows that theory development is often based upon multiple metaphors that interact in complex ways (Boxenbaum \& Rouleau, 2011).

\section{Criteria for Identifying Useful Metaphors}

Weick (1989) and Cornelissen (2006) are among those who have tried to posit criteria for what makes a metaphor useful and valuable in research. Cornelissen (2006) uses the term metaphorical blend to denote the complex package of concepts and relations that people rely on when applying a metaphor. Blend emphasizes that complex metaphors are 
developed through a process of composing, completing and elaborating a set of concepts and relations that are inspired by a source domain to fit a target domain. To distinguish between more and less useful metaphors, Cornelissen (2006), building on Fauconnier and Turner (1998), suggests the application of what he terms optimality principles of metaphorical imagination (see Table 1). These principles test the fit between the metaphor in its source domain and its application in the target domain. The unpacking, concreteness, topology, metonymic tightening, integration and web principles combine to posit that well-known, concrete, source-domain concepts, which have a set of related traits that will allow the manipulation of important aspects of the target domain as a single unit, will facilitate the adoption of a metaphor and increase its usefulness as an analytic tool. Thus, when composing, completing and elaborating metaphors, researchers should attempt to project easily graspable and logically coherent image structures from source to target, while avoiding the creation of image-schematic clashes between the blend and the target (Fauconnier \& Turner, 1998). Partly in dissonance with this, Cornelissen (2006), building on Weick (1989), adds the distance principle, suggesting that a greater semantic distance between source and target domains is desirable, as it will increase the likelihood of novel findings. The good reason principle in Fauconnier \& Turner (1998) recognizes that the interpreter will tend to find significance for each element in the blend; thus this principle advises against the inclusion of aspects that do not entirely hold up to scrutiny or could lead the interpreter astray. Cornelissen (2006) extends this principle to suggest that the designer of a metaphor should strive to explore many aspects of the source domain, even ones that do not at first sight seem relevant, in order to see if they can meaningfully contribute to the metaphor and its capacity to reveal interesting aspects of the target domain. The good reason principle still advises against including connections that are too peripheral.

Table 1 Optimality principles of metaphorical imagination (Cornelissen, 2006, p. 1588)

\begin{tabular}{|l|l|}
\hline Principle & Definition \\
\hline Integration principle & $\begin{array}{l}\text { That representations in the metaphorical blend can be } \\
\text { manipulated as a single unit }\end{array}$ \\
\hline Topology principle & $\begin{array}{l}\text { That relations in the metaphorical blend should match the } \\
\text { relations of their counterparts in other semantic domains }\end{array}$ \\
\hline Web principle & $\begin{array}{l}\text { That the representation in the metaphorical blend should } \\
\text { maintain a relationship to the input target and source concepts }\end{array}$ \\
\hline Unpacking principle & $\begin{array}{l}\text { That, given a metaphorical blend, the interpreter should be } \\
\text { able to infer the structure in relation to other subjects and } \\
\text { applications }\end{array}$ \\
\hline Good reason principle & $\begin{array}{l}\text { That creates pressure to attribute significance to elements in } \\
\text { the metaphorical blend }\end{array}$ \\
\hline principle & $\begin{array}{l}\text { That when metonymically related elements are projected into } \\
\text { the metaphorical blend, there is pressure to compress the } \\
\text { 'distance' between them }\end{array}$ \\
\hline Distance principle & $\begin{array}{l}\text { That the target and source concepts need to come from } \\
\text { semantically distant semantic domains }\end{array}$ \\
\hline Concreteness principle & $\begin{array}{l}\text { That the source concept compared to the target is sufficiently } \\
\text { concrete (rather than abstract) to be understood and } \\
\text { manipulated }\end{array}$ \\
\hline
\end{tabular}


Weick (1989) suggested that the uncovering of useful metaphors starts with the generation of surprise; "that's interesting" signals a contradiction between preconceived notions and experience, providing a reason for further exploration. For metaphors found interesting, he advises that the researcher explore the theoretical, the narrative and the practical applicability, the beauty of the metaphors and the associations to which they give rise. According to Weick (1989), using experience and imagination to explore possible metaphors in this way provides a fast, inexpensive and potentially enlightening test-bed for theory development. Metaphors that survive the test have a potential for contributing to the research field, where other researchers will continue testing them.

\section{Uncovering the Elixir and Mutagen Metaphors}

In our elaboration of metaphors, we have relied on both Weick (1989) and Cornelissen (2006). We have relied on what has caught our attention, and, exploring aspects of fit between source and target domains, arrived at metaphors that capture a number of interesting aspects of the target domain while still exhibiting a high degree of correspondence. The first metaphor, entrepreneurship as elixir, was uncovered through an iterative process, starting with the perception that there is a general tendency to view entrepreneurship as something inherently good. This perception was based on participation in the discourse of entrepreneurship in research seminars and entrepreneurship conferences. These experiences prompted us to scrutinize our own and others' underlying beliefs about the phenomenon, which in turn led us to conduct a literature review of critical views of entrepreneurship and entrepreneurship research. Structuring the critique, we identified several commonalities between the beliefs about entrepreneurship and the elixir concept. This line of reasoning is presented in the next section, Critique of Entrepreneurship Research - The Elixir Metaphor.

Having uncovered the elixir root metaphor, we searched for alternative metaphors within the entrepreneurship field. Although the use of explicit metaphors is often avoided in academic texts (Boxenbaum \& Rouleau, 2011), identifying the instances where they are used is not particularly difficult. Such instances, for example green shoots (Bygrave \& Zacharakis, 2011), road building (Schumpeter, 1934/2008) or engine of growth (Audretsch, 2009), may represent expressions of deeper underlying assumptions, but to constitute root metaphors they must capture a larger and shared idea. Some established metaphors for entrepreneurship arguably qualify as root metaphors. For example, the idea of entrepreneurship as parenthood (Cardon et al., 2005) is shared by many scholars. It is associated with assumptions such as that new firms are fragile and in need of protection and that entrepreneurs are emotionally tied to their ventures. Other examples include bricolage, with its focus on making do with whatever is at hand (Baker, Miner, \& Eesley, 2003; Sarasvathy, 2001, Lévi-Strauss, 1966), opportunity exploitation, with its focus on identification and subsequent exploitation of opportunities (Shane \& Venkataraman, 2000; Shane, 2000), and the notion that entrepreneurship is a mind-set or a method (Sarasvathy \& Venkataraman, 2011). In our further search for root metaphors, we searched for metaphors with the potential to inspire research and possibly also counterbalance the one-sidedly positive images associated with the elixir metaphor. 
Evolution has already been identified as a root metaphor in organizational theory (Boxenbaum \& Rouleau, 2011). The evolutionary metaphor is commonly associated with viewing organizations as organisms and routines as organizational genes (Nelson \& Winter, 1982). However, the analogue to entrepreneurship in that metaphor has not been named. A literature review revealed that the mutagen metaphor has been present in research for a long time, although it has not been made explicit. The starting point for identifying the mutagen metaphor was Schumpeter's (1942/2008) idea of entrepreneurship as the cause of industrial mutations. The line of reasoning behind the mutagen metaphor is presented in the section Evolutionary Perspectives on Entrepreneurship - The Mutagen Metaphor.

To us, both the elixir and the mutagen metaphors, when applied to entrepreneurship research, possess the beauty of compact descriptions. However, the metaphors serve different purposes. While the elixir metaphor is presented as a compact description of a range of problematic aspects entrepreneurship scholars should be mindful of in their research, the mutagen metaphor is presented not only as a counter-metaphor, but also as a candidate for inspiring future research and theory development.

\section{CRITIQUE OF ENTREPRENEURSHIP RESEARCH - THE ELIXIR METAPHOR}

This section summarizes three strands of critique of entrepreneurship research that have surfaced as the entrepreneurship field has become established. The section uses these strands of critiques to establish the elixir metaphor and then finishes by presenting some complications associated with viewing entrepreneurship as elixir.

The label entrepreneurship has moved far beyond business start-ups into contexts such as social, sustainable, public and even criminal entrepreneurship (Sarasvathy \& Venkataraman, 2011; Webb, Tihanyi, Ireland, \& Sirmon, 2009; Baumol, 1990). Despite this diversity of types, the public policy communities are convinced of the merits of entrepreneurship (Acs, Audretsch, \& Strom, 2009; Perren \& Jennings, 2005). Moreover, there is a widespread belief that entrepreneurship is the solution to a wide variety of problems, bearing the promise of alleviating poverty and emancipating women (Mair \& Martí, 2006), resolving global environmental challenges (Cohen \& Winn, 2007; Dean \& McMullen, 2007), creating socially better worlds (Johannisson, 2002), creating jobs and prosperity (Audretsch, 2009) and providing economic vitality (Bygrave \& Zacharakis, 2011). Particularly the latter views of entrepreneurship have resonated with policy makers, which is illustrated by this excerpt from a Swedish parliamentary motion:

Entrepreneurship is the foundation of prosperity. Entrepreneurship is the human force that creates new products, services, and jobs. Entrepreneurship also creates new ways to produce, communicate, consume, and organize life. . . The importance of entrepreneurship and start-ups cannot, therefore, be overestimated. (Pålsson et al., 2004, "Den moderata", para. 4, translated from Swedish by the authors)

Audretsch (2007) claimed that the wealth of regions depends on the entrepreneurial capital of their people, Wiklund (1999) that the wealth of businesses depends on their entrepreneurial orientation, and Quadrini (1999) that the wealth of individual people depends on how entrepreneurial they are. In short, the first strand of critique maintains 
that there is a tendency to view entrepreneurship as something inherently good (Wiklund, 1999) or even as a cure-all (Shane, 2008; Weiskopf \& Steyaert, 2009).

Furthermore, it seems difficult to break with these positive views. Even critical scholars and scholars warning against overly positive views tend to fall back on viewing entrepreneurship as something inherently good. For example, Steyaert and Katz (2004) adopted a critical perspective of entrepreneurship and set out to break with one-sided conceptions of it; still they concluded "indeed, the space of entrepreneurship in society is about nothing less than beauty" (p. 194).

Another example of the first strand of critique is Wiklund (1999), who warned against overly positive views of entrepreneurship, particularly those based on anecdotal evidence. However, as he found that longitudinal data supported a positive relationship between entrepreneurial orientation and firm performance, he concluded, "In light of this, anecdotal evidence about the advantages of entrepreneurship may be beneficial rather than counter-productive to the extent it causes small firms to favor [an entrepreneurial orientation]" (p.44).

In addition, Wiklund (1999) found the positive relationship encouraging to entrepreneurship scholars, which suggests that they have an interest in finding positive aspects of entrepreneurship rather than negative. This is rather reasonable, even if it is seldom articulated. For example, as scholars have an interest in framing research so that it appeals to funding institutions, research highlighting the benefits of the studied phenomenon is helpful (Ogbor, 2000). In attracting funding it is, furthermore, important to frame the research and the phenomenon in a discourse that harmonizes with the worldview and ideology of the funding institution (Ogbor, 2000).

This is intertwined with a second strand of critique of entrepreneurship research, namely that it is often framed in an economistic discourse (Steyaert \& Katz, 2004) and biased towards laissez-faire, neoliberal and market-driven ideologies (Weiskopf \& Steyaert, 2009; Shane 2008). For example, since entrepreneurship is presented as inherently good and something policy makers desire (Perren \& Jennings, 2005), laissezfaire policies can be justified by insisting that they are necessary "not to discourage entrepreneurship" (Chang, 2002 p. 541). In fact, Schumpeter (1942/2008 p. 134) suggested that the capitalist system depends on the proliferation of entrepreneurs and that "the bourgeoisie therefore depends on the entrepreneur [...] and lives and will die with him". This is not confined to political rhetoric; some scholars are likewise advocating policies such as "deregulation, privatization and labor market flexibility" (Audretsch \& Thurik, 2001, p. 269) based on their importance for fostering entrepreneurship.

In this regard, the political and the academic realms are not isolated from each other. For example, the then-president of the European Commission referred to Audretsch, Thurik and other entrepreneurship scholars as he highlighted the importance of entrepreneurship and the need for labor market reforms to support it (Prodi, 2002). Audretsch (2009) in turn referred to Prodi (2002) as he underlined the importance policy makers ascribe to entrepreneurship.

The third strand of critique of entrepreneurship research maintains that the research nourishes a belief in a hidden secret of economic success (Weiskopf \& Steyaert, 2009). This is manifested in the "search for the entrepreneur" (Weiskopf \& Steyaert, 2009, p. 186). The hypothesis is that "the truth about entrepreneurship can be discovered with the help of appropriate scientific methods" (Weiskopf \& Steyaert, 2009, p. 186). For 
example, Aldrich and Kenworthy (1999) explicitly addressed the question why uncovering the secret of successful entrepreneurs is so difficult, despite the fact that entrepreneurs are highly visible. They concluded that this knowledge is not only difficult to articulate, but it is also unlikely that any entrepreneurs who may have discovered the secret would share "their templates for success" (p. 30) with the rest of us, thus indicating a belief in such a secret. The secret is desirable since it promises great financial wealth (Shane, 2008). Indeed, some go further and claim that entrepreneurs can create something from nothing (Ross, 1987; Baker \& Nelson, 2005; Schindehutte, Morris, \& Allen, 2006).

To summarize, this section has identified three different strands of critique of entrepreneurship research: (a) that it portrays entrepreneurship as something inherently good or even a cure-all (Hjorth, Campbell, \& Gartner, 2008; Wiklund, 1999; Shane, 2008; Weiskopf \& Steyaert, 2009); (b) that it is intertwined with market-driven ideologies and used to motivate laissez-faire policies (Weiskopf \& Steyaert, 2009; Steyaert \& Katz, 2004; Perren \& Jennings, 2005; Chang, 2002); (c) that it nourishes a belief in a hidden secret of economic success (Weiskopf \& Steyaert, 2009).

These three strands of critique highlight aspects of entrepreneurship discourse that make entrepreneurship appear strikingly similar to an elixir, suggesting that this is a fitting metaphor. The term elixir has at least four different meanings according to dictionary definitions; it can refer to (a) a cure-all, (b) a sweet medium concealing the taste of a bitter medicine, (c) an alchemic preparation capable of transmuting base metals into gold, and (d) an alchemic potion that revitalizes or prolongs life.

The first three aspects of the elixir metaphor correspond to the three strands of critique identified in this section: entrepreneurship as a cure-all, as a medium concealing the taste of a bitter medicine (e.g. laissez-faire policies) and as the key to economic success. Even the fourth aspect of elixir can be found in entrepreneurship research. For example, Bygrave and Zacharakis (2011) claimed that entrepreneurship vitalizes the economy and Gabrielsson (2007) identified numerous works that claim that corporate entrepreneurship revitalizes business organizations. Together, these aspects of entrepreneurship research contribute to what this paper terms the elixir metaphor for entrepreneurship. The elixir metaphor gives voice to some of the critique of entrepreneurship research that has surfaced as the field has become established and as policy makers have been convinced of the merits of entrepreneurship.

\section{Some Complications of the Elixir View}

Root metaphors influence the way researchers create theoretical models and interpret empirical data. The elixir metaphor can, for example, nudge scholars who find a negative relationship between entrepreneurship and some desirable variable to view the finding as spurious or lead them to look for alternative explanations. An example of the latter is emphasizing non-pecuniary rewards for entrepreneurship when faced with data suggesting a negative relationship between individual entrepreneurial activity and income or wealth accumulation (Carter, 2011). In contrast, alternative explanations are not highlighted with the same intensity when the data suggest that entrepreneurs are financially better off (e.g., Quadrini, 1999). In fact, there seems to be a difference between the way entrepreneurship scholars and scholars outside the field portray the rewards for entrepreneurship (Carter, 2011). 
Furthermore, the elixir view leads to a confused discourse. Talking about entrepreneurship as if it were something inherently good becomes problematic when some include illegal activities in their definitions (Webb et al., 2009; Baumol, 1990). However, simply excluding criminal activities does not justify the elixir view, as legal activities can also have negative effects on society (Davidsson \& Wiklund, 2001; Shane, 2008). In addition, it is possible that some illegal economic activity can have positive effects on society (Webb et al., 2009).

Even though entrepreneurship scholars are labeling subtypes of entrepreneurship - for example, opportunity and necessity (Reynolds et al., 2001; 2005), legal and illegal (Baumol, 1990; Webb et al., 2009), independent and corporate (Sharma \& Chrisman, 1999) and social and commercial (Austin, Stevenson \& Wei-Skillern, 2006) - the generic term often screens out many of the activities logically included in the core definition emergence of new economic activity. This screening out of activities is commonly not articulated, but sometimes it is. For example, Johannisson (2002) associated entrepreneurship with

creative organising and value creation where both the mode of organising (by spontaneity and passion) and the value created (socially better worlds) separates it from instrumental reason and resource efficiency, i.e. phenomena usually associated with management. I also exclude criminal, terrorist and further destructive activities, however creatively organised they may be. (p. 2)

How people define the entities that they study naturally affects what they find. If everything that is destructive is not entrepreneurship, then all entrepreneurship is either neutral or constructive. This invites the question, to whom is a behavior destructive? The evaluation of destructiveness in the social sciences is usually subjective, and it is possible to view most entrepreneurship as having both positive and negative consequences. Ford (to use Johannison's own example) brought cars to the masses, producing many positive effects but also to vastly increased carbon dioxide emissions.

The Pirate Bay is a more recent example of entrepreneurship having ambiguous consequences. It is an Internet site where the general public can post and follow links that direct users to chunks of another file, potentially allowing them to download it. This other file may be copyrighted, making the site a potential facilitator of copyright infringement. Some have claimed that its founders were great entrepreneurs who have instigated Schumpeterian creative destruction (Lewan, 2009). Others have viewed them as common criminals (Dagens Nyheter, 2009, April).

Following Johannison's (2002) advice to exclude criminal activity while taking a current-law view of what is criminal, The Pirate Bay was entrepreneurial when it first started, but would have ceased to be after the change in the law and the first court ruling. If the appeals court had upheld its founders' appeal, however, they would once again have become entrepreneurs. Reserving the word entrepreneurship for what people consider to be desirable innovativeness leads to the inclusion or exclusion based on changing opinions and arbitrarily restricts the cases available for scholars to study.

In summary, the elixir metaphor is derived from a review of critiques of entrepreneurship research that has surfaced as the field has become established. It serves as a compact description of a range of problematic aspects entrepreneurship scholars should be mindful of in their research. 
ENTREPRENEURSHIP AS ELIXIR AND MUTAGEN, Erik Lundmark \& Alf Westelius

Manuscript accepted for publication in Entrepreneurship Theory Practice

\section{EVOLUTIONARY PERSPECTIVES ON ENTREPRENEURSHIP - THE MUTAGEN METAPHOR}

This section explores evolutionary frameworks and the role entrepreneurship plays in them. It finds that although the mutagen metaphor has influenced even the founding works of entrepreneurship literature, it has not been made explicit. Furthermore, it identifies a metaphorical blend that conforms to the optimality principles suggested by Cornelissen (2006).

The function of mutagens is intertwined with the principles of evolution. In fact, mutagens are defined by their tendency to induce variation in evolutionary processes (Parry \& Parry, 2005; Gordo \& Sousa, 2010). Evolution in a Darwinian sense requires variation, selection and inheritance (Darwin, 1859/1962; Dawkins, 1976, 1986). When unmodified, the word tends to refer to biological evolution, but any system that exhibits variation, selection and inheritance is evolving if the selection is systematic and persistent over time (Dawkins, 1986; Aldrich et al., 2008).

In the entrepreneurship literature, evolutionary perspectives have been established for a long time. In fact, the founding work of Schumpeter (1934/2008) has had a profound influence on evolutionary approaches to economics and organizational studies (c.f. Nelson \& Winter, 1982; Aldrich \& Ruef, 2006). However, Schumpeter himself rejected an association with the charged concept of Darwinism (Sandberg, 2007). Nevertheless, in several cases he used such evolutionary terminology as mutation, element of chance, new combinations and the survival of the fittest (Schumpeter, 1954/2006; 1934/2008; 1942/2008).

Applying an evolutionary framework, Aldrich and Ruef (2006), building on Hannan and Freeman (1977), viewed entrepreneurship as a source of variation in organizational ecology. Whether the new variations that entrepreneurship creates live or die depends on how well they are adapted to their social, political, technical, and economic environments. Similarly, Breslin's (2008 p. 404) review of evolutionary approaches to entrepreneurship reveals that the role of entrepreneurship is often centered on inducing variations, which are subsequently exposed to selection forces. Gartner (1993, p. 236) provides a clear example of this, suggesting "that organizational emergence is, at its core, about variation. Each emerging organization is different from all previous organizations." He also emphasized that chance occurrences are the rule, not the exception in this process. In addition, McKelvey (2004, p.330, emphasis added) points out that "[e]ntrepreneurship is about creating blind variation", where the environmental selection comes into play after the blind variation (i.e., mutation) has been created. Similar views, where entrepreneurship creates diversity and the environment weeds out what is dysfunctional, are well established (Sarasvathy, 2001; Anderson, 1999).

In addition, some scholars have specifically claimed that entrepreneurs create mutations. Most notably, Schumpeter (1942/2008) claimed that entrepreneurs instigate creative destruction, which leads to industrial mutations. Another notable scholar sharing this view is Kenneth Arrow, who claimed that "in organized life . . . all sorts of mutations occur. These might be thought of as entrepreneurial efforts" (Sarasvathy, 2000, p. 14). Similarly, McKelvey (1998) claimed that "entrepreneurs generate novelties, mutations, new combinations, etc." Consequently, the idea that entrepreneurship is a source of blind variation and mutations is an idea that has influenced the thoughts of prominent economists and entrepreneurship scholars. 
Seeing entrepreneurship as a source of variation, or more specifically as a source of mutations, makes entrepreneurship appear as if it were a mutagen, as mutagens are a source of mutations. Mutations, in turn, are the ultimate source of variation in biological evolution (Gordo \& Sousa, 2010). Biological mutagens are such agents as ultraviolet light or radioactivity that have a tendency to induce or increase the frequency of genetic mutations (Parry \& Parry, 2005). Conversely, geneticists talk about mutations as innovations (e.g., André \& Godelle, 2006). The mutagen metaphor suggests that entrepreneurship is an inducer of variations in the basic building blocks of organizations. It also suggests that as an agent for such variation, entrepreneurship is myopic or even blind with regards to the viability and effects of its creations.

As demonstrated above, the mutagen metaphor of entrepreneurship has been present in research for a long time, although it has not been made explicit. Making the metaphor explicit makes it easier to identify the basic assumptions associated with it. Furthermore, it can potentially elucidate fruitful paths for entrepreneurship theory development. However, existence and use of a metaphor does not guarantee a good fit between the source and target domains (Weick, 1989; Fauconnier \& Turner, 1998). This paper, therefore, proceeds to explore the extent to which a fit between the mutagen metaphor and entrepreneurship theory and empirical observations can be established.

\section{Fit Between Mutagen and Entrepreneurship}

In the following sub-section, we demonstrate that the mutagen metaphor can serve as the basis for a metaphorical blend which satisfies all criteria for promising metaphors suggested by Cornelissen (2006) (see Table 1). The purpose of this sub-section is to illustrate fit. Therefore, this paper adopts the well-established framework where organizations correspond to organisms, and social, political, technical, and economic environments constitute selection mechanisms (Hannan \& Freeman, 1977; Nelson \& Winter, 1982, Aldrich \& Ruef, 2006). In order to establish a fit between the target and source domains, the metaphorical mutagen needs metaphorical organizational genes to mutate. Although many authors have provided candidates for such a unit (e.g. Dawkins, 1976, Hannan \& Freeman, 1977; Meyer \& Rowan, 1977; Marschak \& Radner, 1972; Stinchcombe, 1965), the term routine, as popularized by Nelson and Winter (1982), is now the established term for the organizational analogue to biological genes.

However, subsequent to Nelson and Winter's (1982) popularization, scholars have diverged on their conceptualizations of routines. Whereas empirical studies tend to emphasize that routines are manifested in behavioral regularities, theoretical work tends to view them as manifested in cognitive regularities (see Becker, 2004 for a review). Hodgson (2003) and Hodgson and Knudsen (2004) combined these two perspectives by claiming that routines are dispositions rather than behaviors. These dispositions involve memory, knowledge, habits and organizational structures. This conceptualization of routines implies that new organizations are not blank slates, rather they get routines largely through combinations of the previous experiences of entrepreneurs, employees, customers, investors and other stakeholders, and they include expectations about the behaviors of others and of ways of doing business (Sarasvathy \& Dew, 2005; Davidsson, Hunter \& Klofsten, 2006; Bryant, forthcoming). In practice, new organizations adopt most of their routines from the population of organizations they join (Aldrich \& Martinez, 2001). The cognitive-regularities aspect of routines is central to inheritance 
processes. For organizational performance, however, the enactment of routines, the behavioral aspect, is what matters. Furthermore, enactment ingrains the ostensive aspect of routines, which is the disposition or the script (Feldman \& Pentland, 2003). Therefore, compared with established organizations, the lack of a shared history in new organizations makes them more fertile ground for producing new routines.

Put in this framework, the mutagen metaphor emphasizes that as entrepreneurs create new organizations or engage in corporate entrepreneurship, they have a tendency to induce mutations in organizational routines. Routines, in turn, are related to the functioning of firms and the success of their products and services. In the biological realm, some mutations are beneficial to the survival of their carriers, but most are detrimental (Elena \& Sanjuán, 2005). This corresponds to newly established organizations having a lower survival rate than that of established ones, to project ideas not leading to projects, to innovative projects closing before completion or not being followed by the implementation of their innovative ideas or products, and to new products having high failure rates (Aldrich \& Auster, 1986; Aldrich \& Martinez, 2001).

One difference between biological mutations and entrepreneurial ones is that the former are unintentional and the latter often intentional. When mutagens change genes, they do so oblivious of any consequences, whereas entrepreneurs often plan and have intentions and visions. This raises the question of whether the entrepreneurial process is random enough for the mutagen metaphor to be valid.

Experience with incubator processes reveals that the viability of entrepreneurial initiatives is notably difficult to judge, even for experts, and is overwhelmingly stochastic, or subject to random factors and chance, which makes picking those that are likely to succeed particularly difficult (Aldrich \& Auster, 1986). Despite common views of entrepreneurship as a deliberate process intended to create value, it is difficult to find factors predicting its outcomes. Entrepreneurship research's survival bias emphasizes the predictable aspects of entrepreneurship by tending to study samples of surviving entrepreneurs (Aldrich \& Martinez, 2001; Aldrich, 1990). Post-hoc sensemaking, furthermore, downplays the unpredictability associated with the journey into Knightian uncertainty (Knight, 1921/2002), as hindsight enables analysts to imagine and present a deliberate route for each specific case (Weick, 1995; Gartner, 1993).

In addition, an empirical approach to entrepreneurial success reveals many findings that do not support the view of entrepreneurship as a deliberate, reasoned, and predictable process. For example, start-up rates are not higher in attractive industries than unattractive ones; rather, the opposite seems to be the case (Shane, 2008). Entrepreneurs, defined as those who create organizations, tend to earn less but work more than they would have done as employees (Shane, 2008; Carter, 2011). Furthermore, although planning has been found to improve the survival rate of entrepreneurial ventures, the merits of planning are debated (Brinckmann, Grichnik, \& Kapsa, 2010), and a recent study following 623 nascent entrepreneurs during a six-year period "found no evidence that planning activities supported enterprise development" (Honig \& Samuelsson, 2012, p. 381). Nevertheless, even if some entrepreneurs have the ability to identify opportunities (Shane \& Venkataraman, 2000) and to plan for their exploitation, they are still constrained by other parties, such as partners, colleagues, customers and investors (Davidsson, Hunter, \& Klofsten, 2006; Sarasvathy \& Dew, 2005; Latour, 1996) and tend 
to improvise. Therefore, viewed from a distance, many of the characteristics of entrepreneurship appear to be more random than deliberate, predictable and planned.

Returning to Cornelissen's (2006) criteria for promising metaphors (see Table 1), the integration, topology, web and metonymic tightening principles refer to the extent to which the metaphor draws on the source domain to construct a useful package of related concepts with applicability to the target domain. The mutagen metaphorical blend presented above does that by incorporating mutagen, gene, mutation, etc., and the relationships between these concepts - all of them meaningfully applicable to the entrepreneurship field.

The unpacking principle suggests that in order for a metaphor to serve a communicative purpose, it should be familiar to the intended reader and the concreteness principle suggests that concrete metaphors are easier to grasp and to use than abstract ones. Mutagens and mutations can be expected to be part of general knowledge and to be concrete enough to allow readers to start thinking about parallels and grasp the use of the metaphor in its target domain.

The good reason principle encourages the exploration of the applicability of all the metaphor's attributes to the target domain. Thus, we have moved from mutation (innovation or deviation), to mutagen (entrepreneurship), to gene (routine), to inheritance (replication of routines) and organism (organization), finding interesting correspondences as we have considered a widening range of attributes from the source domain. The distance principle, finally, suggests that more novel insights can be gained from metaphors with a large rather than small distance between source and target domains. Biology is a domain distant from entrepreneurship. Therefore, the mutagen metaphor conforms to all eight optimality principles proposed Cornelissen (2006), suggesting that it is a viable candidate for conceptual and theoretical development.

In summary, entrepreneurship shares many of the characteristics of mutagens, particularly that both induce changes to the established ways of organizing (organism traits and business routines respectively), where the viability of each mutation is unknown at its outset. A mutagen creates blind variations, some viable but mostly nonviable. Some entrepreneurial initiatives do survive, of course, and some even become new norms for how to conduct business or other activities. Others fail quickly or in the short-to-medium term in a manner similar to the survival or demise of mutated traits in biological evolution. The mutagen metaphor of entrepreneurship is compatible with views of entrepreneurship proposed by some well-established mainstream and critical scholars, such as that it involves organizing, creative organizing, or the breaking of habits and norms (Gartner, 2001; Johannisson, 2002; Weiskopf \& Steyaert, 2009), and by doing so, entrepreneurship assembles, dismantles, and reassembles such things as materials and ideas (Weiskopf \& Steyaert, 2009) and as a result creates new combinations (Schumpeter, 1934/2008). Entrepreneurship is associated with myopic purposefulness that induces random variations (Gartner, 1993; cf. Aldrich, 2011). Furthermore, entrepreneurship can take place while organizations are being founded (Gartner, 1989) or in established organizations (Sharma \& Chrisman, 1999).

\section{REFRAMING ENTREPRENEURSHIP USING THE MUTAGEN METAPHOR}

The previous section has established the existence of the mutagen metaphor and shown a metaphorical blend that can satisfy all of the optimality principles suggested by 
Cornelissen (2006). This section goes on to illustrate how the mutagen metaphor, through disciplined imagination, can be used to reframe previous interpretations of entrepreneurship and its role in the evolution of organizations.

\section{Reframing Existing Conceptualizations of Entrepreneurship}

Arguably, the establishment of new economic activity is intertwined with the establishment of new routines. The role of entrepreneurship in changes to routines depends on how one conceptualizes entrepreneurship. Aldrich and Ruef (2006, p. 63) highlight four major interpretations of entrepreneurship - that entrepreneurship should be seen as: (a) high growth ventures (b) innovative ventures (c) recognition and exploitation of opportunities (d) the creation of new organizations. According to all of these views, entrepreneurship will tend to create new routines. However, the mutagen metaphor could be used to reframe all of these interpretations of entrepreneurship.

In regards to the interpretation of entrepreneurship as high growth ventures, the mutagen metaphor reframes what constitutes high growth. Specifically, the mutagen metaphor suggests that focus should be transferred from the financial performance of a firm to the creation and spread of the new routines and practices, within and outside of the organization of origin (cf. Dawkins, 1976). Although firms may go into liquidation, entrepreneurs can persist with some of their routines in other firms (Sarasvathy, 2004), and some routines might live on in other organizations that have imitated them. The fate of a routine is therefore only to some extent interlinked with the fate of the organization in which it originates. Therefore, the mutagen metaphor also encourages the consideration of the question, what is left when an organization is gone?

Turning to the second interpretation - entrepreneurship as creating innovations the mutagen metaphor rejects the positive connotation that innovation has. Innovation is often defined as something new and useful (cf. pro-innovation bias, Abrahamson, 1991; Rogers, 2003). The mutagen metaphor, in contrast, highlights the deviant nature of entrepreneurship, where only some deviations (i.e., mutations) are fruitful, others have limited effects and yet others are detrimental. Thus, the mutagen metaphor emphasizes that the outcomes of entrepreneurship are not inherently good, and viability does not imply desirability. In fact, some practices may spread quickly between organizations, without necessarily improving the efficiency or effectiveness of the adopting organizations (Abrahamson, 1991; Nelson, Peterhansl, \& Sampat, 2004). Furthermore, routines do not have the same effects in all organizations. The mutagen metaphor suggests why this is not the case. Although it is common to say "a gene for something", most complex traits depend on genes in interaction, so called epistasis (Wilson, 2005).

Regarding entrepreneurship as the recognition and exploitation of opportunity, the mutagen metaphor is compatible with the view that opportunities may exist in the environment (which would allow the mutation to survive and perhaps replicate). However, the metaphor, with its emphasis on blind variation, is pessimistic about entrepreneurs' abilities to perceive, let alone act to predictably exploit, opportunities. The mutagen metaphor suggests the successful exploitations of opportunities are the result of myopic guesses or chance events rather than opportunity recognition. Therefore, even remarkable successes leading to the formation of new industries do not require inferring that entrepreneurs are more knowledgeable or have abilities different in kind or even degree to those of non-entrepreneurs (cf. Coşgel, 1996; Jones \& Spicer, 2005). 
Lastly, although the interpretation of entrepreneurship as the creation of new organizations may give an impression of radical newness, the mutagen metaphor emphasizes that even new organizations inherit most routines from the populations they join. Nevertheless, many new firms develop some new routines, either as a deliberate process or as a random error in an attempt at replicating existing ones. Consequently, the mutagen metaphor suggests that entrepreneurship scholars should focus not only on what is new, but also on what is replicated in organizations that are innovative (or deviant). Arguably, previous experiences are important in replicating routines (Klepper, 2002; 2011). However, rather than viewing previous experience as unambiguously beneficial, the mutagen metaphor suggests that prior experiences may impede attempts to deviate from current practices. Therefore, many of the sources of inertia identified in existing organizations (e.g., Hannan \& Freeman, 1977; Giddens, 1984; Tushman \& Anderson, 1986; Boeker, 1989; Cohen \& Levinthal, 1990), are applicable, through mechanisms of inheritance, also in founding processes. The imprinting process in new firms is therefore a promising area for future research (Bryant, forthcoming).

\section{Reframing the Role of Entrepreneurship in the Evolution of Organizations}

This sub-section reviews different sources of new routines in organizations and then discusses what roles the mutagen metaphor suggests entrepreneurship play in the evolution of organizations.

Hannan and Freeman (1977) contrasted two stylized mechanisms by which populations of organizations evolve. The first mechanism is the strategic adaptation of organizations to fit the environment. The second mechanism is the selection of the best adapted organizations by the environment. They argued that established organizations tend to be constrained by structural inertia, which limits their possibilities to adapt to the environment. Therefore, they argued, the appearance of adaptation could be caused largely by the selection of the best adapted organizations in a given environment. In their framework, new organizations are the primary source of variation from which the environment selects. However, all variation does not emanate from actions of founders or managers. An alternative explanation for the adaptation of organizations is provided by the literature on dynamic capabilities. This literature suggests that organizations may change routines in routinized ways through meta-routines (Adler, Goldoftas, \& Levine, 1999; Winter, 2003). Furthermore, routines can change randomly, as when a key employee suddenly resigns and the remaining staff needs to find new ways of working to fill the gap (Nelson \& Winter, 1982). In addition, routines are sometimes mutated in attempts to imitate successful organizations, to follow influential people's normative advice, or as organizations expand (Aldrich \& Ruef, 2006; Feldman \& Pentland, 2003; DiMaggio \& Powell, 1983; Abrahamson, 1991; 1996). Thus, the literature suggests that new routines are created by deliberate action by people in new and established organizations, by meta-routines and by unintended changes to existing routines as they are enacted or imitated.

Because meta-routines and incremental changes can create the new routines, identifiable entrepreneurs are not a prerequisite for the creation of new economic activity (cf. Schumpeter, 1942/2008). Accordingly, organizational founders do not always play the main role in the emergence of new economic activity (cf. Baumol, 1968). Is there then something that separates entrepreneurship from accidental changes to routines 
caused by someone leaving their job (Nelson \& Winter, 1982) or the routinized changes to routines often involved in product development (Winter, 2003)? The mutagen metaphor suggests that entrepreneurship can be interpreted as the deliberate and nonroutine attempt at creating routines with the aim of creating new economic activity. In doing so, entrepreneurs break habits, norms and routines and create new ones. In this interpretation, entrepreneurship is distinct from the routinized creation of new routines as well as from accidental changes to routines as they are being enacted. Entrepreneurship can take place in new as well as established organizations, and in capitalist as well as other types of societies. By this interpretation, entrepreneurship plays a distinct role in creating the new variations that are necessary for long-term evolution of organizations, both in the creation of new organizations and in the adaptation of existing ones. This interpretation shifts the focus from the question of whether adaptation or selection is the most important factor in the evolution of organizations (Hannan \& Freeman, 1977; Aldrich \& Ruef, 2006), to the relative importance of various sources of variation and their accuracy.

In contrast to both the routinized and accidental changes of routines, the interpretation of entrepreneurship as the deliberate attempt at creating new routines is associated with agency. Despite emphasizing that previous experiences may constrain entrepreneurial choice, the mutagen interpretation contrasts with the view that entrepreneurship is driven by conformist non-decisions (Meyer, 2008). However it does not depict entrepreneurship as driven by what Meyer (2008) refers to as fully autonomous rationalized actors either. Rather, the mutagen interpretation depicts entrepreneurship as blind or myopic non-conformism, which generates variations that enable change.

\section{Reframing Desirable Levels of Entrepreneurship}

If newness is regarded as something generally valuable, it could be expected that higher mutation rates would always be preferred to lower ones. However, in biological research, the concept that mutation rates can be too high is well established (Elena \& Sanjuán, 2005; Gordo \& Sousa, 2010; Sanjuán \& Domingo-Calap, 2011). The reason is that organisms are generally well adapted to their environment, and thus the number of mutations that decrease fitness is much larger than the number of those that increase it. The value of mutations derives from the variation that can help a population adapt to changes in the environment. When changes to the environment occur, a low rate of mutation generally implies slow adaptation, and as the rate increases, so does adaptation. However, mutation rates can reach levels where adaptation is thwarted, due to the accumulation of detrimental mutations that are not weeded out. In the ideal condition that a population is optimally adapted to the environment, no levels of mutation would improve fitness. Consequently, a mutagen in itself is not sufficient for systematic evolution (although drift can occur, Whitlock \& Phillips, 2001). The selective pressure, weeding out the less fit from the more fit, plays an important role. In evolutionary theory, this is discussed in terms of the breadth of the fitness peak occupied by the population. A narrow fitness peak would mean that deleterious changes would be strongly selected against, while a broader peak would mean that a broader range of deleterious changes could survive (Elena \& Sanjuán, 2005).

Viewing entrepreneurship as an organizational mutagen therefore suggests that (a) evolution of organizations is not just dependent on the level of entrepreneurship but also 
on what is selected and how strongly; (b) in particular, more entrepreneurship does not always lead to faster adaptation given a selective pressure; and (c) changes in the environment, which in turn change what contributes to fitness, generally increase the marginal benefit of entrepreneurship (until adaptation has occurred).

This has implications for our prospect to understand the relationship between entrepreneurship and economic growth at a societal level. The mutagen metaphor of entrepreneurship implies that our chances of understanding this relationship are low. The reason is that, given the assumption that adaptation to the environment contributes to economic growth, optimal levels of entrepreneurship depend on many elusive factors that are likely to change over time. Evolutionary patterns, for example, are likely to be different for different industries. It is impossible to know how far an industry is from its local optimum, and even if knowing this were possible, such optima are likely to change over time. It is also extremely difficult to determine when new events will change the environment and by how much. Finding an optimal level for any particular industry is therefore unlikely, and if someone were to find one, it would soon be obsolete. This may be the reason empirical research has not found a consistent pattern between the level of entrepreneurship and economic growth (Audretsch \& Keilbach, 2005; Kelley, Bosma, \& Amorós, 2011). The improbability of finding an optimal level does not, however, imply that research on the association between different measures of entrepreneurship and quantitative growth is futile, only that it would at best produce crude heuristics.

These crude heuristics could include theoretical claims about events that increase the need for entrepreneurship, given the aim of economic growth. In fact, the mutagen metaphor is theoretically aligned with the recent research associating entrepreneurship and economic growth (Audretsch, 2007; Acs, Braunerhjelm, Audretsch, \& Carlsson, 2009). This research suggests that entrepreneurship is contributing to economic growth through commercializing new knowledge created through research. The mutagen metaphor suggests a theoretical interpretation of this in that new knowledge changes what is possible and as a consequence changes the selection process and the fitness peak. This in itself is not sufficient for economic growth; these new possibilities must be implemented in changed behavioral patterns. Entrepreneurship introduces new routines and thus plays the role of a mutagen. In other words, as new knowledge changes the environment, entrepreneurship, in its role as a mutagen, enables adaptation. However, this does not imply that more entrepreneurship necessarily leads to faster adaptation, nor does it imply that the viable new practices are necessarily desirable.

\section{DISCUSSION AND CONCLUSION}

This paper has identified two root metaphors in entrepreneurship research: elixir and mutagen. Uncovering root metaphors is important because they profoundly influence both people's perceptions and the way people make sense of those perceptions. Yet, the use of metaphors is often downplayed in, or even consciously removed from, academic publications (Boxenbaum \& Rouleau, 2011). Therefore, there is reason to believe that the uncovered metaphors have been more influential in research design and interpretation of empirical observations than their presence in published research suggests. Nevertheless, as demonstrated in this paper, the literature provides many reflections of the two uncovered root metaphors. 
The elixir metaphor reveals that entrepreneurship can sometimes be construed as a cure-all, as a medium concealing the taste of a bitter medicine, as the hidden secret to economic success and as a revitalizer for economies or business organizations. Consciously or unconsciously, such views risk nudging scholars towards one-sidedly looking for, and highlighting, positive aspects of entrepreneurship. The elixir metaphor, which is blatantly positive, serves as a compact description of a range of problematic aspects entrepreneurship scholars should be mindful of in their research. Nevertheless, entrepreneurship scholars may benefit from alluding to this metaphor. It may, for example, have contributed to the increasing interest in entrepreneurship among policy makers and researchers during the last couple of decades. The elixir metaphor holds a natural appeal for politicians, looking for cure-alls and well-defined recipes for improvement. With politicians providing funding for research, scholars may be encouraged to support positively biased views of entrepreneurship. However, the discourse on entrepreneurship changes over time, and it is possible that we are currently in a period of particularly favorable attitudes towards entrepreneurship among policy makers and in society in general (Audretsch, 2009). Researchers are part of society and therefore influence and are influenced by the general discourse in media and among policy makers. Therefore, the fate of the elixir metaphor is only partly in the hands of the entrepreneurship research community. It is possible that we will see attitudes towards entrepreneurship change both in kind and degree in the coming decades. However, the entrepreneurship field is now so well established that it is not dependent on the elixir metaphor for its survival, if it ever were. In fact, continued use of the elixir metaphor may turn out to be a liability for entrepreneurship research, because such use risks decreasing the credibility of the field.

In contrast to the elixir metaphor, this paper finds mutagen a promising metaphor for inspiring theory development, and it identifies a blend that conforms to all of the optimality principles suggested by Cornelissen (2006). The paper has used the mutagen metaphor to discipline imagination (Weick, 1989) and provide examples of how that metaphor reframes entrepreneurship. The mutagen metaphor suggests that entrepreneurship can be interpreted as deliberate, but blind or myopic, non-conformism with the aim of creating new economic activity. In doing so, entrepreneurs break habits, norms and routines and create new ones. In this interpretation, entrepreneurship is distinct from the routinized creation of new routines (Winter, 2003) as well as from accidental changes to routines as they are being enacted (Nelson \& Winter, 1982). The mutagen metaphor is compatible with the view that entrepreneurship can take place both in new and established organizations. Furthermore, it emphasizes that much of the inertia restricting deviation in established firms is present also in the founding process of organizations. New firms are not blank slates; rather, they get many dispositions and scripts through combinations of the previous experiences of entrepreneurs, employees, customers, investors and other stakeholders and they include expectations about the behaviors of others and of ways of doing business (Sarasvathy \& Dew, 2005; Davidsson, Hunter \& Klofsten, 2006; Bryant, forthcoming). The mutagen metaphor suggests that the successful exploitations of opportunities are the results of myopic guesses or chance events rather than opportunity recognition. In regards to the outcomes of entrepreneurship, the metaphor invites a shift in focus from the growth of firms to the propagation of practices or routines. The metaphor suggests that entrepreneurship, in its 
role as a mutagen, enables organizational adaptation. However, the mutagen metaphor does not imply that more entrepreneurship necessarily leads to faster adaptation, nor does it imply that the viable new practices are necessarily desirable. This is fundamental to the view of entrepreneurship as mutagen, as new ventures are not inherently good, and success does not entail any particular norm for morality and virtue. As a consequence, the mutagen metaphor removes blinders which screen out aspects logically included in the core definition emergence of new economic activity.

This paper has argued that despite entrepreneurs' intentions or beliefs about opportunities, the outcome of entrepreneurial ventures is best modeled as stochastic. This should not be interpreted as the authors suggesting that any random change to organizational routines has the same likelihood of creating viable "mutations" as a deliberate attempt by an entrepreneur. It is possible that different mutagens have different propensities to create viable mutations. In addition, empirical results may come to suggest that particular entrepreneurial methods (Sarasvathy \& Venkataraman, 2011) may produce outcomes that tend to be more viable than those produced by other methods. This could be interpreted as a refined typology of mutagens or, for those who are so inclined, as some mutagens being more intelligent than others. The mutagen metaphor, nevertheless, challenges the research community by illustrating mechanisms by which entrepreneurship can create new viable practices or even new industries without inferring that entrepreneurs are more knowledgeable or have abilities different in kind or even degree compared to non-entrepreneurs (cf. Coşgel, 1996; Jones \& Spicer, 2005).

As with the elixir metaphor, indeed any metaphor, scholars should be mindful of how the mutagen metaphor influences their research. This metaphor exhibits a strong fit with entrepreneurship, but entrepreneurship is not a mutagen and analogy is not proof. The point of using metaphors is to derive inspiration for new ways to look at the research topic through disciplined imagination. It is not to attempt to prove that the source domain and the target domain correspond in every conceivable way. This paper has proposed a metaphorical blend where the source domain supplies a number of related concepts, such as mutagen (entrepreneurship), gene (routine), mutation (deviant routines), and inheritance (imitation of routines). In this paper's application of these concepts to the entrepreneurship field, this metaphorical blend makes sense and offers a new frame worth exploring further. However, like any metaphor, attempting to view entrepreneurship as a mutagen can give rise to various metaphorical blends. Some transfers of meaning between source and target domain provide more direct analogies; others only provide interesting, but not complete analogies. Although the metaphor can be explored further, somewhere there is a limit where the transfer of meaning between source and target domain breaks down. As with any metaphor, some blends make sense, some do not. For example, as replication of genes in the biological realm is different from the replication of routines in organizations, the analogy should be limited to the passing on of some kind of generative information between entities (Hodgson, 2003). Furthermore, there are many different types of evolutionary processes within biological evolution. For example, the evolutions of organisms with sexual and asexual reproduction differ in many respects. Both these evolutionary dynamics are different from the evolution of organizations. Therefore, in exploring the metaphor further, it is important to discipline imagination and to search for and use analogies that make sense. For someone just noting the label mutagen, starting to elaborate freely, the term might primarily suggest carcinogenic 
changes, all being for the worst, or, in a sci-fi tradition, might trigger an image of new organisms with supernatural powers, good or evil. This paper emphasizes that the useful analogy between entrepreneurship and mutagens centers on the general and less valueladen meaning mutagen has to evolutionary biologists, which is an inducer of blind variation.

Furthermore, mutagen, like any metaphor, emphasizes some aspects and hides others. This paper has pointed out that many entrepreneurs both plan and act deliberately, whereas a mutagen is totally oblivious to its consequences. In other words, the mutagen metaphor depersonalizes entrepreneurship, perhaps even contributing to expunging the hero from the story (Baumol, 1968). Consequently, this metaphor has little to offer to researchers interested in, for example, the motivations of entrepreneurs or the reasoning behind entrepreneurial actions.

One way to identify the blind spots of a metaphor is to contrast it with another metaphor, as different metaphors highlight and downplay different aspects of the target domain. Multiple metaphors, therefore, vouch for more nuanced views of entrepreneurship. For example, the mutagen metaphor addresses some of the complications associated with the elixir one. It clearly moderates the elixir metaphor's cure-all aspect and the view of entrepreneurship as revitalizing by indicating that entrepreneurship can lead to, but does not guarantee, economic and other types of development and by refuting the idea that more entrepreneurship is always better. It also reframes the elixir metaphor's suggestion that there is a secret of entrepreneurial success (Weiskopf \& Steyaert, 2009). Since the mutagen metaphor emphasizes the venture into Knightian uncertainty, it provides little hope of finding the secret of successful entrepreneurship, and instead implies that what is already known is at the periphery of entrepreneurship. People can learn how to start and run a business, or a crime syndicate for that matter, but for the mutagenic event there is little prior knowledge.

By noting and critiquing the politicization of the elixir metaphor, this paper does not claim that the mutagen one is free from political dramaturgy. Its focus on our bounded rationality could, just as the elixir view, be used as an argument for laissez-faire policies. Conversely, the importance of the selection process could tempt some to try to manipulate it. For example, putting pressure on car manufacturers to decrease carbon dioxide emissions or trying to promote such entrepreneurial initiatives as those that policy makers believe to have a potential for growth would alter the selection process. Making certain activities illegal is another way of manipulating the selection process. The mutagen metaphor may consequently have little to offer from the perspective of exposing or discouraging political agendas or other bitter medicines, and perhaps invites a wider spectrum of possible political agendas to link themselves with the entrepreneurship field.

Furthermore, although the metaphors highlight and downplay quite different aspects of entrepreneurship, they can be combined. For example, in contexts where the level of entrepreneurship is very low, it could appear as an elixir. The combination of the metaphors would suggest that, in such a setting, most entrepreneurial efforts would still fail, but at an aggregate level the effects would be positive - mutagen would be elixir at the aggregate level. Consequently, the metaphors should not be seen as each other's opposites, but rather as two different metaphors with clearly different emphases.

Finally, this paper presents the elixir metaphor as a means for staying aware of pro-entrepreneurship biases and the mutagen metaphor as a tool for reframing 
entrepreneurship. The mutagen metaphor is not proposed as the one correct or best image of entrepreneurship. Other metaphors could highlight blind spots of the mutagen metaphor. Some of the following candidates were suggested, but not further explored in this paper: parenthood (Cardon et al., 2005), bricolage (Baker et al., 2003; Sarasvathy, 2001; Lévi-Strauss, 1966); opportunity exploitation (Shane \& Venkataraman, 2000; Shane, 2000); and entrepreneurship as a mind-set or method (Sarasvathy \& Venkataraman, 2011). All of these seem like interesting candidates, and there are probably more. Entrepreneurship scholars could benefit from gathering a body of metaphors for our object of study similar to what organizational scholars have done with theirs (Morgan, 1986). We believe that making an effort to change perspectives by sometimes zooming in on a phenomenon to inspect it closely, and at times observing it from a distance, benefits research outcomes and consequently the overall understanding of entrepreneurship. We hope, therefore, that future research will not only exploit the mutagen metaphor and heed the message of the elixir metaphor, but also contribute to the identification of other metaphors with the potential to reframe entrepreneurship. 
ENTREPRENEURSHIP AS ELIXIR AND MUTAGEN, Erik Lundmark \& Alf Westelius

Manuscript accepted for publication in Entrepreneurship Theory Practice

\section{REFERENCES}

Abrahamson, E. (1991). Managerial Fads and fashion: The diffusion and rejection of innovations. Academy of Management Review, 16(1), 586-612.

Abrahamson, E. (1996). Management fashion. Academy of Management Review, 21(1), 254-285.

Acs, Z. J., Audretsch, D. B., \& Strom, R.J. (2009). Why entrepreneurship matters. In Z. J. Acs, D. B. Audretsch, \& R. J. Strom (Eds.), Entrepreneurship, growth, and public policy (pp. 1-14). New York, NY: Cambridge University Press.

Acs, Z. J., Braunerhjelm, P., Audretsch, D. B., \& Carlsson, B. (2009). The knowledge spillover theory of entrepreneurship. Small Business Economics, 32(1), 15-30.

Adler, P. S., Goldoftas, B., Levine, D. I. (1999). Flexibility versus efficiency? A case study of model changeovers in the Toyota production system. Organization Science, 10(1), 43-68.

Aldrich, H. (1990). Using an ecological perspective to study organizational founding rates. Entrepreneurship Theory and Practice, 14(3), 7-24.

Aldrich, H. E. (1992). Incommensurable paradigms? Vital signs from three perspectives. In M. Reed \& M. Hughes (Eds.), Rethinking organisation: New directions in organisation theory and analysis (pp. 17-45). London, UK: Sage.

Aldrich, H. E. (2011). Heroes, villains, and fools: Institutional entrepreneurship, NOT institutional entrepreneurs. Entrepreneurship Research Journal, 1(2), Article 2. Available at: http://www.bepress.com/erj/vol1/iss2/2 DOI: 10.2202/21575665.1024

Aldrich, H. E. \& Auster E. R. (1986). Even dwarfs started small: Liabilities of age and size and their strategic implications. In B. M. Staw \& L. L. Cummings (Eds.), Research in organizational behavior, (pp. 165-198). Greenwich, CT: JAI Press.

Aldrich, H. E., Hodgson, G. M., Hull, D. L., Knudsen, T, Mokyr, J., \& Vanberg, V. J. (2008). In defence of generalized Darwinism. Journal of Evolutionary Economics, 18(5), 577-596.

Aldrich, H. E. \& Kenworthy, A. L. (1999). The accidental entrepreneur: Campbellian antinomies and organizational foundings. In J. A. C. Baum and B. McKelvey (Eds.), Variations in organization science: Essays in honor of Donald T. Campbell (pp. 19-33) Newbury Park, CA: Sage.

Aldrich, H. E. \& Martinez, M. A. (2001). Many are called, but few are chosen: An evolutionary perspective for the study of entrepreneurship. Entrepreneurship Theory \& Practice, 25(4), 41-56.

Aldrich, H. E. \& Ruef, M. (2006). Organizations evolving (2nd ed.). Thousand Oaks, CA: Sage.

Anderson, P. (1999). Venture capital dynamics and the creation of variation through entrepreneurship. In J.C. Baum and B. McKelvey (eds.), Variations in organization science, in honor of Donald T. Campbell (pp. 137-153). New York: Sage.

André, J-B. \& Godelle, B. (2006). The evolution of mutation rate in finite asexual populations. Genetics, 172(1), 611-626. doi: 10.1534/genetics.105.046680.

Audretsch, D. B. (2007). Entrepreneurship capital and economic growth. Oxford Review of Economic Policy, 23(1) 63-78. 
ENTREPRENEURSHIP AS ELIXIR AND MUTAGEN, Erik Lundmark \& Alf Westelius

Manuscript accepted for publication in Entrepreneurship Theory Practice

Audretsch, D. B. (2009). The entrepreneurial society. Journal of Technology Transfer, 34(3), 245-254.

Audretsch, D. B. \& Keilbach, M. (2005). The mobility of economic agents as conduits of knowledge spillovers. In D. Fornahl, C. Zellner, \& D. B. Audretsch (Eds.), The role of labour mobility and informal networks for knowledge transfer (pp. 8-26). Boston, MA: Springer.

Audretsch, D. B. \& Thurik, A. R. (2001). What's new about the new economy? Sources of growth in the managed and entrepreneurial economies. Industrial and Corporate Change, 19(1), 267-315.

Austin, J., Stevenson, H., \& Wei-Skillern, J. (2006). Social and commercial entrepreneurship: Same, different, or both? Entrepreneurship Theory and Practice, 30(1), 1-22. doi: 10.1111/j.1540-6520.2006.00107.x

Baker, T \& Nelson, R. E. (2005). Creating something from nothing: Resource construction through entrepreneurial bricolage. Administrative science quarterly, 50(3), 329-366. doi: 10.2189/asqu.2005.50.3.329

Baker, T., Miner, A.S., \& Eesley, D.T. (2003). Improvising firms: Bricolage, account giving and improvisational competencies in the founding process. Research Policy, 32(2), 255-276.

Baumol, W. J. (1968). Entrepreneurship in economic theory. The American Economic Review, 58(2), 64-71.

Baumol, W. J. (1990). Entrepreneurship: Productive, unproductive, and destructive. Journal of Political Economy, 98(5), 893-921.

Becker, M. C. (2004). Organizational routines: A review of the literature. Industrial and Corporate Change, 13(4), 643-678.

Berger, P. \& Luckmann, T. (1966) The social construction of reality. New York, NY: Doubleday.

Boeker, W. (1989). Strategic change: The effects of founding and history. Academy of Management Journal, 32(3),489-515.

Boxenbaum, E. \& Rouleau, L. (2011). New knowledge products as bricolage: Metaphors and scripts in organizational theory. Academy of Management Review, 36(2), 272-296.

Breslin, D. (2008). A review of the evolutionary approach to the study of entrepreneurship. International Journal of Management Reviews, 10(4), 399-423.

Brinckmann, J., Grichnik, G., \& Kapsa, D. (2010). Should entrepreneurs plan or just storm the castle? A meta-analysis on contextual factors impacting the business planning-performance relationship in small firms. Journal of Business Venturing 25(1), 24-40.

Bryant, P. (forthcoming). Imprinting by design: The microfoundations of entrepreneurial adaption. Manuscript accepted for publication in Entrepreneurship Theory and Practice.

Bygrave, W. \& Zacharakis, A. (2011). Entrepreneurship (2nd ed.) Hoboken, NJ: John Wiley \& Sons.

Cardon, M.S., Zietsma, C., Saparito, P., Matherne, B.P., \& Davis, C. (2005). A tale of passion: New insights into entrepreneurship from a parenthood metaphor. Journal of Business Venturing, 20(1), 23-45. 
Carter, S. (2011). The rewards of entrepreneurship: Exploring the incomes, wealth, and economic well-being of entrepreneurial households. Entrepreneurship Theory and Practice, 35(1), 39-55.

Chang, H.-J. (2002). Breaking the mould: An institutionalist political economy alternative to the neo-liberal theory of the market and the state. Cambridge Journal of Economics, 26(5), 539-559.

Cohen, B. \& Winn, M. I. (2007). Market imperfections, opportunity and sustainable entrepreneurship. Journal of Business Venturing, 22(1), 29-49.

Cohen, W. M. \& Levinthal, D. A. (1990). Absorptive capacity: A new perspective on learning and innovation. Administrative Science Quarterly, 35(1), 128-152.

Cornelissen, J. P. (2006). Making sense of theory construction: Metaphor and disciplined imagination. Organization Studies, 27(11), 1579-1597.

Coşgel, M.M.(1996). Metaphors, stories, and the entrepreneur in economics. History of Political Economy, 28(1), 57-76.

Czarniawska, B. \& Sköldberg, K. (1998). Organiserandet - en berättelse som sätts på scen [Organising - a story cast on stage]. In Czarniawska (Ed.), Organisationsteori på svenska [Organisation theory in Swedish]. Malmö, Sweden: Liber.

Dagens Nyheter (2009, April 18). Ledare: En viktig dom [Editorial: An important verdict]. Dagens Nyheter. Retrieved from http://www.dn.se/opinion/huvudledare/ ledare-en-viktig-dom-1.846847

Darwin, C. (1859/1962). The origin of species by means of natural selection or the preservation of favoured races in the struggle for life. New York, NY: Collier Books.

Davidsson, P., Hunter, E., \& Klofsten, M. (2006). Institutional forces: The invisible hand that shapes venture ideas. International Small Business Journal, 24(2), 115-129.

Davidsson, P. \& Wiklund, J. (2001). Levels of analysis in entrepreneurship research: Current research practice and suggestions for the future. Entrepreneurship Theory and Practice, 25(4), 81-99.

Dawkins, R. (1976). The selfish gene. Oxford, UK: Oxford University Press.

Dawkins, R. (1986). The blind watchmaker. Harlow, UK: Longman Group UK Limited.

Dean, T. J. \& McMullen, J. S. (2007).Toward a theory of sustainable entrepreneurship: Reducing environmental degradation through entrepreneurial action. Journal of Business Venturing, 22(1), 50-76.

DiMaggio, P.J. \& Powell W.W. (1983) The iron cage revisited: Institutional isomorphism and collective rationality in organizational fields. American Sociological Review, 48(2), 147-160.

Dodd, S. D. (2002). Metaphors and meaning: A grounded cultural model of US entrepreneurship. Journal of Business Venturing, 17(5), 519-535.

Elena, S.F. \& Sanjuán, R. (2005). Adaptive value of high mutation rates of RNA viruses: Separating causes from consequences. Journal of Virology, 79(18), 11555-11558.

Fauconnier, G. \& Turner, M. (1998). Conceptual integration networks. Cognitive Science, 22(2) 133-187.

Feldman, M.S. \& Pentland, B.T. (2003). Reconceptualizing organizational routines as a source of flexibility and change. Administrative Science Quarterly, 48(1), 94-118. 
Gabrielsson, J. (2007). Boards of directors and entrepreneurial posture in medium-size companies - Putting the board demography approach to a test. International Small Business Journal, 25(5), 511-537.

Gartner, W. B. (1989). Who is an entrepreneur? Is the wrong question. Entrepreneurship Theory \& Practice, 13(4) 47-68.

Gartner, W. B. (1993). Words lead to deeds: Towards an organizational emergence vocabulary. Journal of Business Venturing 8(3), 231-239.

Gartner, W. B. (2001). Is there an elephant in entrepreneurship? Blind assumptions in theory development. Entrepreneurship, Theory and Practice, 25(4), 27-39.

Giddens, A. (1984) The constitution of society: Outline of the theory of structuration. Cambridge, England: Polity Press.

Gordo, I. \& Sousa, A. (2010) Mutation, selection and genetic interactions in bacteria. In: Encyclopedia of life sciences (ELS). Chichester, UK: John Wiley \& Sons. DOI: 10.1002/9780470015902.a0022175 (8 pages).

Hannan, M.T. \& Freeman, J. 1977.The population ecology of organizations. American Journal of Sociology, 82(5), 929-964.

Hill. R. C. \& Levenhagen, M. (1995). Metaphors and mental models: Sensemaking and sensegiving in innovative and entrepreneurial activities. Journal of Management, (21)6, 1057-1074.

Hjorth, D., Campbell, J., \& Gartner, B. (2008). Introduction for 'recreating/ recontextualising' entrepreneurship. Scandinavian Journal of Management, 24(2), 81-84.

Hodgson. G.M. (2003). The mystery of the routine - The Darwinian destiny of an evolutionary theory of economic change. Revue économique, 54(2), 355-384.

Hodgson, G. M. \& Knudsen, T. (2004). The firm as an interactor: Firms as vehicles for habits and routines. Journal of Evolutionary Economics, 14(3), 281-307.

Honig, B. \& Samuelsson, M. (2012). Planning and the Entrepreneur: A Longitudinal Examination of Nascent Entrepreneurs in Sweden. Journal of Small Business Management, 50(3), pp. 365-388

Hyrsky, K. (1999). Entrepreneurial metaphors and concepts: An exploratory study. International Small Business Journal, 18(1), 13-34. doi: 10.1177/0266242699181001

Johannisson, B. (2002, September). Enacting entrepreneurship: Using auto-ethnography to study organisation creation. Paper presented at the Conference of Ethnographic Organisational Studies, University of St. Gallen, Switzerland. Retrieved from http://vxu.se/ehv/filer/forskning/entreprofil/publikationer/johannissonstgallen03. doc

Jones, C. \& Spicer, A. (2005). The sublime object of entrepreneurship. Organization, 12(2), 223-246.

Kelley, D., Bosma, N., \& Amorós, J. E. (2011). Global entrepreneurship monitor 2010 global report. Available at: http://www.gemconsortium.org/download.asp?fid=1093

Klepper, S. (2002). The capabilities of new firms and the evolution of the US automobile industry. Industrial and Corporate Change, 11(4), 645-666. doi: 10.1093/icc/11.4.645 
Klepper, S. (2011). Nano-economics, spinoffs, and the wealth of regions. Small Business Economics, 37(2), 141-154. doi:10.1007/s11187-011-9352-5

Knight, F. H. (1921/2002). Risk, uncertainty and profit. Washington, DC: Beard Books.

Koiranen, M. (1995). North-European metaphors and of 'entrepreneurship' and 'an entrepreneur'. Frontiers of entrepreneurship research. Babson College, Wellesley, MA, pp. 203-216. Available at: www.babson.edu

Lakoff, G. P. \& Johnson, M. (1980). Metaphors we live by. Chicago, IL: University of Chicago Press.

Latour, B. (1996). Aramis, the love of technology. Cambridge, MA.: Harvard University Press.

Lewan, M. (2009). Pirate Bay: Visioner i krock med korsförhör [Pirate Bay: Visions in collision with cross-examinations]. Ny Teknik. Retrieved from http://www. nyteknik.se/nyheter/it_telekom/allmant/article525699.ece

Mair, J. \& Martí, I. (2006). Social entrepreneurship research: A source of explanation, prediction, and delight. Journal of World Business, 41(1), 36-44.

Marschak, J. \& Radner, R. (1972). Economic theory of teams. New Haven, CT: Yale University Press.

McKelvey, B. (1998). Evolutionary innovations: Learning, entrepreneurship and the dynamics of the firm. Journal of Evolutionary Economics, 8(2), 157-175.

McKelvey, B. (2004). Toward a complexity science of entrepreneurship. Journal of Business Venturing, 19(3), 313-341.

Meyer, J.W. (2008). Reflections on institutional theories of organizations. In R. Greenwood, C. Oliver, R. Suddaby and K. Sahlin (Eds.), (pp. 788-809) The Sage handbook of organizational institutionalism. Los Angeles, CA: Sage.

Meyer, J.W. \& Rowan, B. (1977). Institutionalized organizations: Formal structure as myth and ceremony. The American Journal of Sociology, 83(2), 340-363.

Morgan, G. (1986). Images of organization. Thousand Oaks, CA: Sage.

Nelson, R. R., Peterhansl, A., \& Sampat, B. (2004). Why and how innovations get adopted: A tale of four models. Industrial and Corporate Change, 13(5), 679-699.

Nelson, R. R. \& Winter, S. G. (1982). An evolutionary theory of economic change. Cambridge, MA: Harvard University Press.

Nicholson, L. \& Anderson, A. R. (2005). News and nuances of the entrepreneurial myth and metaphor: Linguistic games in entrepreneurial sense-making and sensegiving. Entrepreneurship Theory and Practice, 29(2), 153-172.

Ogbor, J. O. (2000). Mythicizing and reification in entrepreneurial discourse: Ideologycritique of entrepreneurial studies. Journal of Management Studies, 37(5), 605635. doi: 10.1111/1467-6486.00196

Palmer, I. \& Dunford. R. (1996). Conflicting uses of metaphors: Reconceptualizing their use in the field of organizational change. Academy of Management Review, 21(3) 691-717.

Parry, J. M. \& Parry, E. M. (2005). Environmental mutagenesis. In: Encyclopedia of life sciences (ELS). Chichester, UK: John Wiley \& Sons. doi: 10.1038/npg.els.0005559

Pepper, S. (1982). Metaphor in philosophy. Journal of Mind and Behavior, 3(3), 197-206. 
Perren, L. \& P. Jennings (2005). Government discourses on entrepreneurship: Issues of legitimization, subjugation, and power. Entrepreneurship Theory and Practice, 29(2), 173-184.

Prodi, R. (2002). For a new European entrepreneurship. Europa press releases RAPID, Reference: SPEECH/02/49. Retrieved from http://europa.eu/rapid/ pressReleasesAction.do?reference=SPEECH/02/49\&format=HTML\&aged= $1 \&$ language $=E N \&$ guiLanguage $=e n$

Pålsson, A.-M., Hammarbergh, K., Kjellberg, B., Danielsson, P., Hagfeldt, S., Karlsson, U., \& Sjölund, A. (2004). Villkor för regional utveckling [Conditions for regional development]. Motion till riksdagen 2004/05:N397 [Parliamentary motion]. Retrieved from http://www.riksdagen.se/sv/DokumentLagar/Forslag/Motioner/Villkor-for-regional-utvecklin_GS02N397/?text=true

Quadrini, V. (1999). The importance of entrepreneurship for wealth concentration and mobility. Review of Income and Wealth, 45(1) 1-19.

Reynolds, P., Bosma, N., Autio, E., Hunt, S., De Bono, N., Servais, I., Lopez-Garcia, P., $\&$ Chin, N. (2005). Global entrepreneurship monitor: Data collection design and implementation 1998-2003. Small Business Economics, 24(3), 205-231. DOI 10.1007/s11187-005-1980-1

Reynolds, P. D., Camp, S. M., Bygrave, W. D., Autio, E., \& Hay, M. (2001). Global entrepreneurship monitor 2001 executive report. Available at http://www.gemconsortium.org/about.aspx?page=global_reports_2001

Rogers, E.M. (2003). Diffusion of innovations, 5th ed., New York, NY: The Free Press. Ross, J. (1987). Corporations and entrepreneurs: Paradox and opportunity. Business Horizons, 30(4), 76-80.

Sandberg, M. (2007). The evolution of IT innovations in Swedish organizations: A Darwinian critique of 'Lamarckian' institutional economics. Journal of Evolutionary Economics. 17(1), 1-23.

Sanjuán, R. and Domingo-Calap, P. (2011) Experimental evolution in viruses. In: Encyclopedia of life sciences (ELS). Chichester, UK: John Wiley \& Sons. doi: 10.1002/9780470015902.a0022857 (7 pages).

Sarasvathy, S. D. (2000). Report on the seminar on research perspectives in entrepreneurship. Journal of Business Venturing, 15(1), 1-57.

Sarasvathy, S. D. (2001). Causation and effectuation: Toward a theoretical shift from economic inevitability to entrepreneurial contingency. The Academy of Management Review, 26(2), 243-263.

Sarasvathy, S. D. (2003). Entrepreneurship as a science of the artificial. Journal of Economic Psychology, 24(2), 203-220.

Sarasvathy, S. D. (2004). The questions we ask and the questions we care about: Reformulating some problems in entrepreneurship research. Journal of Business Venturing, 19(5), 707-717.

Sarasvathy, S.D. \& Dew, N. (2005). New market creation through transformation. Journal of Evolutionary Economics, 15(5), 533-565.

Sarasvathy, S. D. \& Venkataraman, S. (2011). Entrepreneurship as method: Open questions for an entrepreneurial future. Entrepreneurship Theory and Practice, 35(1), 113-135. doi: 10.1111/j.1540-6520.2010.00425.x 
ENTREPRENEURSHIP AS ELIXIR AND MUTAGEN, Erik Lundmark \& Alf Westelius

Manuscript accepted for publication in Entrepreneurship Theory Practice

Schindehutte, M., Morris, M., \& Allen, J. (2006). Beyond achievement: Entrepreneurship as extreme experience. Small Business Economics, 27(4-5), 349-368. doi:10.1007/s11187-005-0643-6

Schumpeter, J. A. (1934/2008). The theory of economic development: An inquiry into profits, capital, credit, interest and the business cycle. London, UK: Transaction Publishers.

Schumpeter, J. A. (1942/2008). Capitalism, socialism and democracy. New York, NY: Harper Collins.

Schumpeter, J. A. (1954/2006). History of economic analysis. UK: Taylor and Francis.

Shane, S. (2000). Knowledge and the discovery of entrepreneurial opportunities. Organization Science, 11(4), 448-469.

Shane, S. A. (2008). The illusions of entrepreneurship: The costly myths that entrepreneurs, investors, and policy makers live by. New Haven, CT: Yale University Press.

Shane, S. \& Venkataraman, S.(2000). The promise of entrepreneurship as a field of research. Academy of Management Review, 25(1), 217-226.

Sharma, P. \& Chrisman, J. J. (1999). Toward a reconciliation of the definitional issues in the field of corporate entrepreneurship. Entrepreneurship Theory and Practice, 23(4), 11-27.

Simon, H. A. (1997). Administrative behavior. New York, NY: The Free Press.

Steyaert, C., \& Katz, J. (2004). Reclaiming the space of entrepreneurship: Geographical, discursive and social dimensions. Entrepreneurship and Regional Development, 16(3), 179-196.

Stinchcombe, A.L. (1965). Social structure and organizations. In J.G. March (Eds), Handbook of organizations (pp. 153-93). Chicago, IL: Rand McNally.

Tushman, M.L. \& Anderson, P. (1986). Technological discontinuities and organizational environments. Administrative Science Quarterly, 31(3), 439-465.

Webb, J. W., Tihanyi, L., Ireland, R. D., \& Sirmon, D. G. (2009). You say illegal, I say legitimate: Entrepreneurship in the informal economy. Academy of Management, 34(3), 492-510.

Weick, K. E. (1989). Theory construction as disciplined imagination. Academy of Management Review, 14(4): 516-531.

Weick, K. (1995). Sensemaking in organisations. London, UK: Sage.

Weiskopf, R. \& Steyaert, C. (2009). Metamorphoses in entrepreneurship studies: Towards affirmative politics of entrepreneuring. In D. Hjorth \& C. Steyaert (Eds.), The politics and aesthetics of entrepreneurship. A fourth movements in entrepreneurship book. Cheltenham, UK: Edward Elgar.

Whitlock, M. C. \& Phillips, P. C. (2001). Drift: Introduction. In: Encyclopedia of life sciences (ELS). Chichester, UK: John Wiley \& Sons.

Wiklund, J. (1999). The sustainability of the entrepreneurial orientation-performance relationship. Entrepreneurship Theory and Practice, 24(1), 37-48.

Wiklund, J., Davidsson, P., Audretsch D. B., \& Karlsson, C. (2011). The Future of entrepreneurship research. Entrepreneurship Theory and Practice, 35(1), 1-9. doi: $10.1111 / \mathrm{j} .1540-6520.2010 .00420 . \mathrm{x}$

Winter, S.G. (2003) Understanding dynamic capabilities. Strategic Management Journal, 24(10), 991-995. 
ENTREPRENEURSHIP AS ELIXIR AND MUTAGEN, Erik Lundmark \& Alf Westelius

Manuscript accepted for publication in Entrepreneurship Theory Practice

Wilson, S.R., (2005). Epistasis. In: Encyclopedia of life sciences (ELS). Chichester, UK: John Wiley \& Sons. doi: 10.1038/npg.els.0005414 